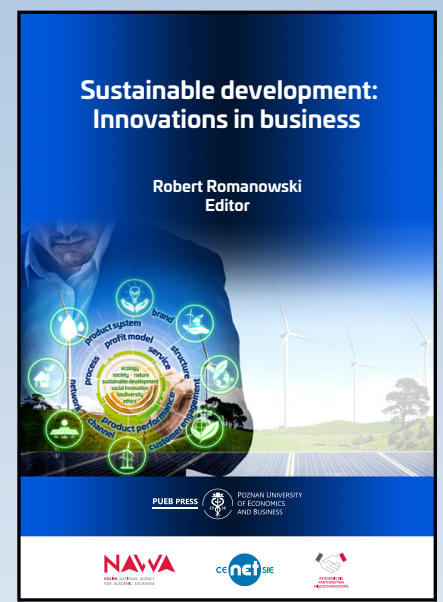

\title{
Sustainable development: Innovations in business
}

\section{Robert Romanowski Editor}

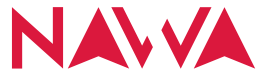

POLISH NATIONAL AGENCY

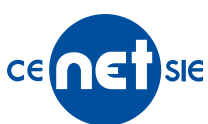

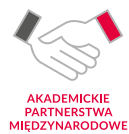

elSBN 978-83-8211-084-5

https://doi.org/10.18559/978-83-8211-084-5

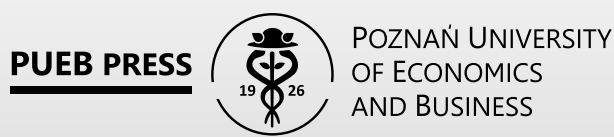

(c) Copyright by Poznań University of Economics and Business Poznań 2021

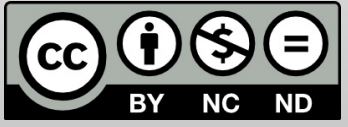

This textbook is available under the Creative Commons 4.0 license - AttributionNoncommercial-No Derivative Works 


\title{
4.
}

\section{PROCESS AS AN INNOVATION}

\section{Lyubcho Varamezov}

D. A. Tsenov Academy of Economics

\section{Iskra Panteleeva}

D. A. Tsenov Academy of Economics

\begin{abstract}
The aim of the chapter is to present key essential aspects of innovation and their species diversity. Basic definition formulations are considered. The emphasis is on business process innovation. One case study of company from Bulgaria that has implemented business process innovations is described, as well as the results of the innovation changes. With the help of various cognitive, analytical, inductive-deductive, case and simulation methods, students achieve the acquisition of new knowledge by combining theoretical statements, including familiarity with some international standards, and practical skills based on the principle of learning by doing. The topic draws students' attention to the need for a comprehensive examination of the issues of innovative change and the formation of economic thinking, oriented towards the implementation of business solutions for sustainable prosperity based on innovative development.
\end{abstract}

Keywords: business process innovations, business process innovations models, innovations, innovation activities. 


\subsection{Introduction}

The contemporary business environment is extremely dynamic, difficult to predict and risky. It creates preconditions for "shining" on the market and at the same time-for a quick exit from the market dimensions. There are often changing configurations of market players, reformatting of company and sectoral borders, globalization of markets, strong and often unfair competition, variable regulations/deregulations, growing need for digitalization, etc. These processes are accompanied by a sharp increase in the strength of customers and the pressure they exert on companies. Customers demand fast and convenient provision of products and/or services, with an increasing number and complex combination of utilities as a package of solutions, with an optimal "quality / price" ratio. Such an environment challenges companies to be flexible and adaptable, to follow the call of the market, which requires constant changes in company systems, in the activities they perform, in the way and their role of participation in other systems external to the company. The business aspiration to adapt to the market dimensions is focused on the search and implementation of innovative solutions, part of which are the various changes in the business processes conducted in companies. The aim of the chapter is to present key essential aspects of innovation and their species diversity.

\subsection{Theoretical background}

Companies can implement business processes, developing their activities on a function-oriented or process-oriented principle. Function-oriented companies construct activities by allocating tasks to functions (e.g., research and development, production, purchasing and delivery, etc.). The process-oriented company focuses on the key processes both within the company and its structural units, as well as on the most important processes that take place as a continuous interaction with external entities and organizational units. Process-oriented companies are better positioned to market expectations and customer needs, as they are more adaptable to changes in the business environment (KGiSL, 2020).

Within the process point of view, two definition approaches can be additionally identified: from the point of view of production theory and of system-oriented company theory. Within production theory, the emphasis is on the transformation function of a process. "A process is triggered by an event; this event serves as an indicator for the occurrence of a defined state. Within a process, an object (input of the process) is subject to different activities. These activities make changes to the object, thus changing the original state. The changed object leaves the process and 
defines the output of the process" (KGiSL, 2020). System-oriented theory allows a more differentiated view of the relationships between the elements (tasks, task managers, material resources and information) of the company and between the company and its environment, with three types of connections and relationships (KGiSL, 2020):

- Deliverables connections and relationships-include assigning tasks to task managers and material resources;

- Sequence connections and relationships-include the division of labour and the resulting dependencies between tasks;

- Information and communication connections and relationships-develop on the basis of management relationships and consistency. They connect tasks, i.e., task and machine managers through information.

Business process management is a concept for model-based design, coordination and implementation of business processes (see Figure 4.1).

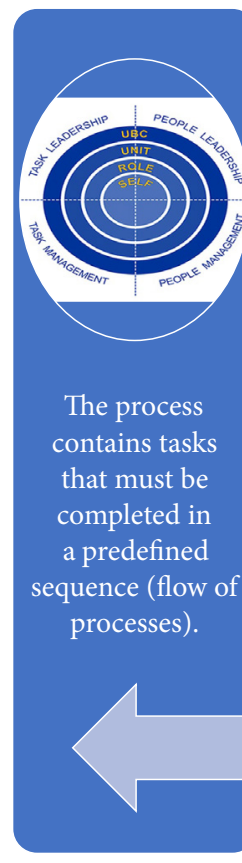

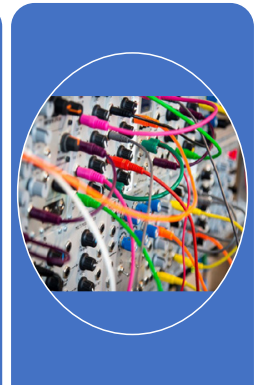

Tasks are

supported or

activated by

technology.

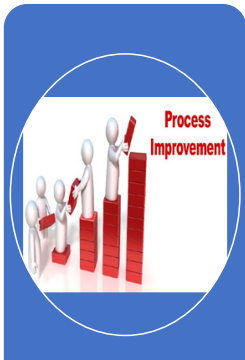

The results of the process represent the added value of the process and are delivered

to internal or external customers.

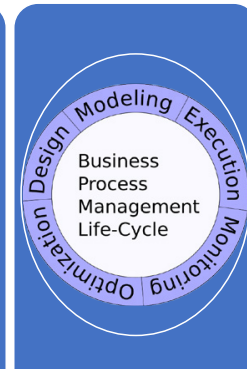

Process management consists of critical success

factors,

performance

indicators and

target values.

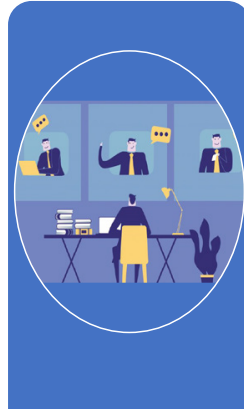

The process

manager is

responsible for managing the processes.

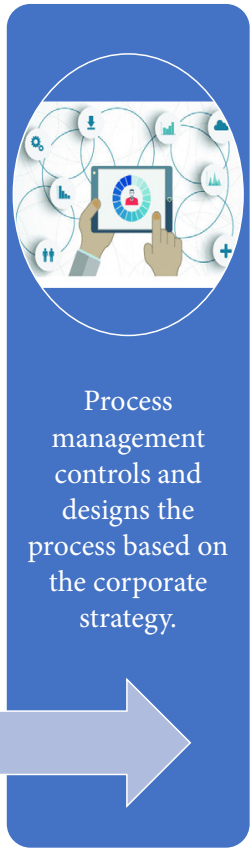

Figure 4.1. Key points of reference in Business Process Management

Source: Adapted according to (KGiSL, 2020).

Techopedia describes a business process as "a wide range of structured, often chained, activities or tasks conducted by people or equipment to produce a specific service or product for a particular user or consumer [in order] to accomplish 
a predetermined organizational goal". In simpler terms, "processes entail the combination of corporate resources, such as facilities, skills, and technologies, to reach an organizational goal" (Techopedia. Dictionary, 2020).

According to the terminology in Oslo Manual the business process includes

the core business function of producing goods and services and supporting functions such as distribution and logistics, marketing, sales and after-sales services; information and communication technology (ICT) services to the firm, administrative and management functions, engineering and related technical services to the firm, and product and business process development. Business processes can be considered as services for which the firm itself is the customer. (Eurostat/ OECD, 2018, p. 72).

It can be delivered in-house or procured from external sources.

The main aspect in the context of process management is customer orientation through the following four approaches (KGiSL, 2020):

- Customer satisfaction: Identifying and satisfying customer needs using process deliverables.

- Quality: Ensuring the process quality (nature of the process deliverables) by means of constant measurements (comparison of target vs. current values) and derivation of measures.

- Time management: Reduction of throughput times (an event that triggers the process up to the availability of the process deliverables for process customers).

- Process costs: Planning of overall costs/cost rates of processes and tasks as well as the derivation of efficiency-enhancing measures.

Business innovations are related to the conscious use of information, imagination and initiative to extract larger or different values, and include all the processes that generate new ideas and make them useful. In this sense, business innovation has a number of characteristics, the more important of which include (Varamezov, 2005, pp. 11-12; Panteleeva, 2013, p. 28):

- the subject (what changes and how it changes);

- degree of novelty;

- depth of transformation (degree of variance radicality);

- scale of transformation (affects one, several spheres of activity or enterprise as a whole);

- level of development (level of preparedness for implementation);

- the potential (evaluation of the expected beneficial effect and its justification);

- expected duration of deployment;

- labour-intensive implementation;

- volume of financial costs required for implementation, etc. 


\subsection{Process innovations-definition aspects, parameters, types and examples}

The process itself can be seen as a sequence of steps to achieve a certain result. Innovation is associated with identifying and implementing a different / unique way for achieving a desired result. By implementing and integrating the two conceptual approaches (for process and innovation) we can define process innovation as the "implementation of a production or delivery method" (including a method indirectly related to the company's products and services) "that is completely new or has undergone significant improvements". Changes in software, technology and equipment, processes to improve the performance of HR or Finance functions, etc., are examples of process innovations (Process innovation steps, 2016; American Society for Quality, 2021; Terjesen \& Patel, 2015).

According to Oslo Manual business process innovation is "a new or improved business process for one or more business functions that differs significantly from the firm's previous business processes and that has been brought into use in the firm" (Eurostat/OECD, 2018, p. 72). Based on the basic principles defining the processes and their management in the companies, terminological clarity can be given regarding the process innovations. Prospects for innovation change can be result- or process-oriented. In the result-oriented innovation perspectives, the efforts are focused on the realization of quality innovations based on the innovation object, the level of innovation and the reference unit for determining the property of the novelty. Process innovations aim at efficient production of products and/or provision of services. Within the process-oriented innovation perspective, process innovations are implemented on the basis of a structured approach with a series of tasks and solutions that are logically and temporally related to each other. Tasks are used to develop and implement processes. Innovation objects are the individual elements of the processes (e.g., tasks, results, etc.) or the whole process. Process innovations are complex probabilistic solutions that bring benefits and effects as a result of changes within the three types of the business processes: Valuecreating processes, Support processes and Management processes (KGiSL, 2020) (see Figure 4.2).

The implementation of process innovations requires the combination (within a given environment) of material and financial resources, technologies, structures and skills, thus enabling the company to save money and time in the production of products and/or the provision of services that meet market demands more in terms of parameters, quality, convenience, speed and price. The redesign of the processes looks for the intersections between the parameters that create market attraction and the parameters that provide the company with an additional boost to success. 


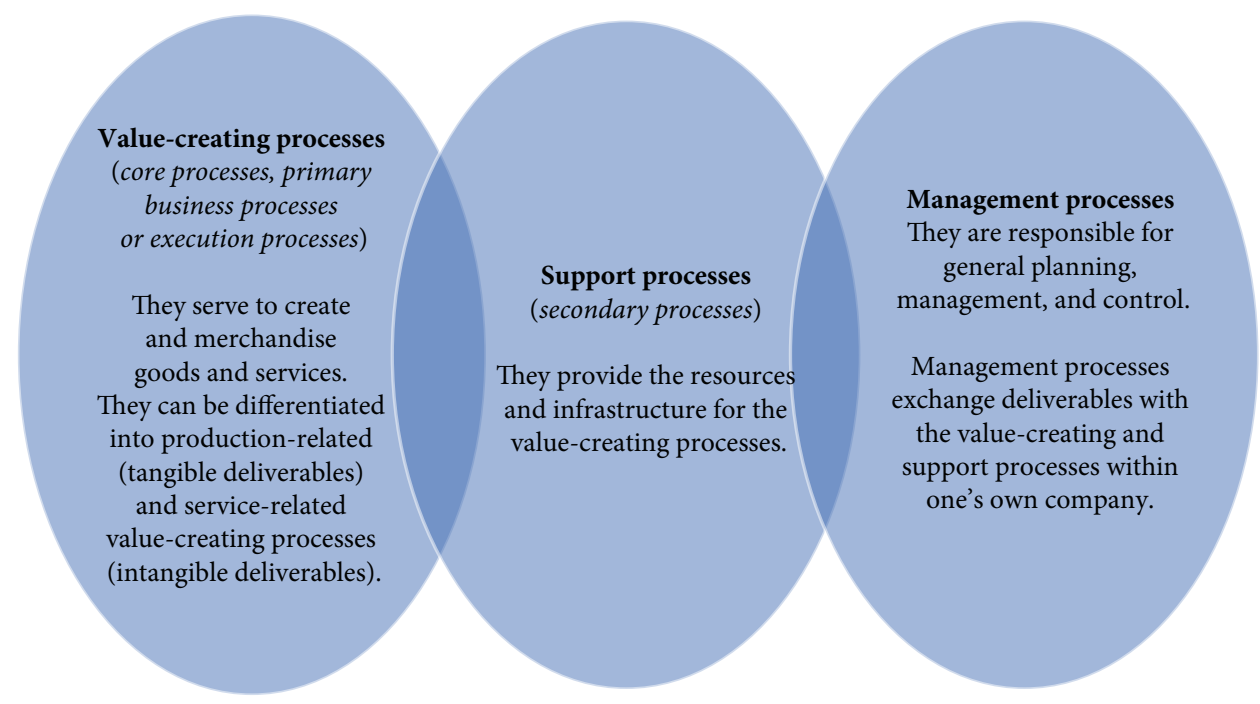

Figure 4.2. Types of business processes in terms of possible process boundaries for the implementation of process innovations

Source: Adapted according to (KGiSL, 2020).

The dynamics in the environment and the mechanisms of doing business have led to changes in the way and scope of reporting and collecting information about the innovation activity of companies. As a natural response to the need to define an objective terminological basis for measuring the empirical projections of the innovation behaviour of structural formations in various fields, changes were made to the Oslo Manual and a new version of this standard was adopted. Relevant links were made between the two versions from 2005 and 2018. Compared to the previous edition, in the new version of the manual the scope of process innovations has been expanded (see Table 4.1).

Many of the process innovations are not easily visible to the market, especially those introduced within companies, but reflect on changes in market dimensions, and are effective for a number of players in the value chain. Process innovations are related to changes in the equipment and technologies used, team development, changes in rules and procedures, leading to positive effects for all stakeholders.

The increasingly common classification perspective, according to Doblin's model (Doblin.com, 2013) provides an opportunity to define innovation from a more pragmatic point of view. According to Doblin's systematization of innovations one of 10 types of innovation (innovation approach) is process innovation. This type of innovation is identified "when the processes inside the company are improved for their efficiency either to reduce production time or to reduce certain costs". 
Table 4.1. Functional categories for identifying the type of business process innovations

\begin{tabular}{|c|c|c|}
\hline \multicolumn{2}{|c|}{ Short term } & Details and subcategories \\
\hline \multirow[t]{3}{*}{$\begin{array}{l}\text { Process } \\
\text { innova- } \\
\text { tions }\end{array}$} & $\begin{array}{l}\text { Production } \\
\text { of goods or } \\
\text { services }\end{array}$ & $\begin{array}{l}\text { Activities that transform inputs into goods or services, including engineering } \\
\text { and related technical testing, analysis and certification activities to support } \\
\text { production. }\end{array}$ \\
\hline & $\begin{array}{l}\text { Distribution } \\
\text { and logistics }\end{array}$ & $\begin{array}{l}\text { This function includes: } \\
\text { a) transportation and service delivery; } \\
\text { b) warehousing; } \\
\text { c) order processing. }\end{array}$ \\
\hline & $\begin{array}{l}\text { Information and } \\
\text { communication } \\
\text { systems }\end{array}$ & $\begin{array}{l}\text { The maintenance and provision of information and communication systems, } \\
\text { including: } \\
\text { a) hardware and software; } \\
\text { b) data processing and database; } \\
\text { c) maintenance and repair; } \\
\text { d) web-hosting and other computer-related information activities. } \\
\text { These functions can be provided in a separate division or in divisions respon- } \\
\text { sible for other functions. }\end{array}$ \\
\hline $\begin{array}{l}\text { Market- } \\
\text { ing }\end{array}$ & $\begin{array}{l}\text { Marketing and } \\
\text { sales }\end{array}$ & $\begin{array}{l}\text { This function includes: } \\
\text { a) marketing methods including advertising (product promotion and place- } \\
\text { ment, packaging of products), direct marketing (telemarketing), exhibi- } \\
\text { tions and fairs, market research and other activities to develop new markets; } \\
\text { b) pricing strategies and methods c) sales and after-sales activities, including } \\
\text { help desks other customer support and customer relationship activities. }\end{array}$ \\
\hline $\begin{array}{l}\text { Organiza- } \\
\text { tional }\end{array}$ & $\begin{array}{l}\text { Administration } \\
\text { and manage- } \\
\text { ment }\end{array}$ & $\begin{array}{l}\text { This function includes: } \\
\text { a) strategic and general business management (cross-functional decision- } \\
\text { making), including organizing work responsibilities; } \\
\text { b) corporate governance (legal, planning and public relations); } \\
\text { c) accounting, bookkeeping, auditing, payments and other financial or insur- } \\
\text { ance activities; } \\
\text { d) human resources management (training and education, staff recruitment, } \\
\text { workplace organization, provision of temporary personnel, payroll manage- } \\
\text { ment, health and medical support); } \\
\text { e) procurement; } \\
\text { f) managing external relationships with suppliers, alliances, etc. }\end{array}$ \\
\hline N/A & \begin{tabular}{l|} 
Product and \\
business process \\
development
\end{tabular} & $\begin{array}{l}\text { Activities to scope, identify, develop, or adapt products or a firm's business } \\
\text { processes. This function can be undertaken in a systematic fashion or on an ad } \\
\text { hoc basis, and be conducted within the firm or obtained from external sources. } \\
\text { Responsibility for these activities can lie within a separate division or in divi- } \\
\text { sions responsible for other functions, e.g., production of goods or services. }\end{array}$ \\
\hline Product & \multicolumn{2}{|c|}{$\begin{array}{l}\text { Goods and services include knowledge-capturing products, and combinations thereof. Includes } \\
\text { the design characteristics of goods and services. }\end{array}$} \\
\hline \multicolumn{3}{|c|}{ Main classification according to Oslo Manual } \\
\hline $\begin{array}{l}\text { Oslo } \\
\text { Manual } 3 \\
\text { ed. }\end{array}$ & \multicolumn{2}{|c|}{$\begin{array}{l}\text { Oslo Manual } \\
4 \text { ed. }\end{array}$} \\
\hline
\end{tabular}

Source: Based on (Eurostst/OECD, 2018, pp. 73-74; Brown, 2008, Eurostat, 2018). 
Process innovations show how the company uses signature or superior methods to do its work (Innovating society, 2020a). Process innovations "often form the core competency of an enterprise and may include patented or proprietary approaches" (Innovating society, 2020b). It is considered the least risky form of innovation, probably because it usually aims at minimizing costs, rather than driving revenues. As a consequence, it has attracted less enthusiasm and attention from entrepreneurs, executives and scholars (Databerg, 2021).

In defining the directions and dimensions of process innovations from the positions of the Doblin Model, we can rely on the sample general base map of Deloitte (Doblin.com, 2013) (see Figure 4.3).

Process Standardization: Use common products, processes, procedures, and policies to reduce complexity, costs, and errors.

Localization: Adapt an offering, process, or experience to target a culture or region.

Process Efficiency: Create or produce more while using fewer resources-measured in materials, energy consumption or time.

Flexible Manufacturing: Use a production system that can rapidly react to changes and still operate efficiently.

Process Automation: Apply tools and infrastructure to manage routine activities in order to free up employees.

Crowdsourcing: Outsource repetitive or challenging work to a large group of semi-organized individuals.

OrDemand Production: Produce items after an order has been received to avoid carrying costs of inventory.

Lean Production: Reduce waste and cost in your manufacturing process and other operations.

Logistics Systems: Manage the flow of goods, information and other resources between the point of origin and the point of use.

Strategic Design: Employ a purposeful approach that manifests itself consistently across offerings, brands, and experiences.

Intellectual Property: Protect an idea that has commercial value-such as a recipe or industrial process-with legal tools like patents.

User Generated: Put your users to work in creating and curating content that powers your offerings.

Predictive Analytics: Model past performance data and predict future outcomes to design and price offerings accordingly.

Figure 4.3. Sample general base map of Deloitte in defining the directions and dimensions of process innovations from the positions of the Doblin Model

Source: Based on (Doblin.com, 2013).

A large number of business process innovation cases can be cited, for example (Panteleeva, 2013, p. 43):

- the introduction of new automated production line equipment;

- the design of product changes using new computer software; 
- the introduction of a bar code or active RFID (radio frequency identification) system for tracking goods;

- the introduction of GPS devices for tracking transport services;

- the introduction of a new reservation system in a travel agency;

- the development of new project management techniques in a consulting firm.

- the application of new or significantly improved information and communication technologies (ICT).

The most frequently cited examples of innovative change in type of process innovation include:

- Ford: Henry Ford introduces a production line in his car company's production processes, which leads to significant changes in the process and the way of assembling vehicles, improves the use of timing and significantly reduces the production time of a vehicle from 12 hours to 1,5 hours (Differential, 2020).

- Grupo Bimbo: Bimbo introduces a dashboard for mobile sales, which provides quick access to information about queries, sales, other KPIs, shortens meeting time, decision-making, resource allocation and results (Differential, 2020).

- McDonald's: The sale of franchise in the late 1940s, as well as the creation of call centers for remote ordering from many restaurants in the United States, led to the optimization of time organizational indicators and a rapid increase in economic results (Innovating society, 2020a).

- Google: Process innovation in the field of human resources, related to offering employees $20 \%$ of their working time to be free to carry out personal projects contributed to the realization of multifaceted benefits for the company (Innovating society, 2020b).

The ability to identify precisely potentially successful innovative ideas and to transform them into working business sentences in a timely manner is essential for companies. The implementation of successful process innovations brings multifaceted benefits that lead to increased efficiency and improved profitability of the company. Some of the business benefits of innovation in the process include as follows (Upadhyay, 2020):

- Process innovation adds value by improving the overall supply chain, realizing cost efficiency, improving the quality of products and services, improving the brand image, increasing productivity and achieving overall company growth.

- Achievement of greater flexibility and adaptability to customer needs by applying new ways to develop and deliver improved products or services to the market.

- The composition and structure of the workforce are optimized; better customer engagement and work efficiency are achieved.

- Competitive differentiation is realized on the basis of improving business processes, including in an operational manner, on the basis of better customer service and gaining more experience. 


\subsection{Factors affecting process innovations}

The process of developing new products and technologies, and implementing different process innovations is influenced by a number of factors. These factors act in different ways-some stimulate the process innovations, while others delay the development or directly block the innovative activity of the company. Despite the rich variety of factors, they can be classified into several main groups (Varamezov, 2013, pp. 50-58):

- Techno-economic. Stimulating: availability of a reserve of financial and material-technical means; availability of the necessary scientific and technical potential; compliance of the new product with the existing technology, production experience and marketing system of the company; material stimulation of the innovation activity, etc. Obstructive: lack of funds to finance innovative projects; weak scientific and technical base; lack of reserve capacity; non-compliance of the new product with the existing technology, production experience and marketing system of the company; dominance of the interests of the current production, orientation towards short-term purchase of costs, etc.

- Legal and regulatory. Incentives: legislative measures stimulating innovation (tax breaks, preferences, etc.). Obstructive: restrictions by antitrust, tax and patent law.

- Organizational and managerial. Stimulating: flexibility of organizational and management structures; democratic style of governance, predominance of horizontal information flows and informal relations; decentralization, autonomy; support from senior management; good interaction between functional departments; availability of long-term plans and clearly defined goals; correct identification of needs; presence of an energetic organizer of the innovation process, etc. Obstructive: firmly established organizational structures with excessive centralization, conservatism of organizational and management structures, hierarchical principles of construction, predominance of vertical information flows; lack of support from senior management; poor interaction between functional departments; lack of long-term plans and clearly defined goals; formalism; orientation towards short-term return on investments, departmental closure; lack of an energetic organizer of the innovation process, etc.

- Socio-psychological. Stimulating: public recognition, moral and material encouragement, providing conditions for self-realization, creative atmosphere, tolerance of failure, etc. Obstructive: resistance to changes that may lead to changes in status, the need to look for a new job, breaking stereotypes of behaviour; fear of uncertainty; penalties for failure, etc.

The influence of factors outside the company also deserves attention. In particular, the problem of the influence of the national culture, or rather of some of its features (individualism, collectivism), on the process of developing new 
process innovations has become especially acute. In a society with a high degree of individualism, the connection between its members is lost, as each individual is concentrated on his own interests and the interests of their immediate environment. Examples of countries with a high degree of development of individualism include the United States, Great Britain, Canada and Italy. A society with a low degree of individualism (for example, Japan, Iran, Taiwan, and Colombia) adheres to group values and pursues collective interests. Although sociologists have studied this feature of national culture quite thoroughly, they practically ignore the influence of individualism in the process of developing new products.

Research by specialists in the field of innovation management gives sufficient grounds to assume that a high degree of individualism can be associated with the successful development of process innovations. The practice shows that new of process developers are people who are committed to new ideas. Even if others see one idea or another as not worth the cost of resources, these people, in spite of everyone, challenging colleagues, try to find answers to complex, intricate questions. Their intransigence, self-confidence and perseverance are the driving force in the innovation process, which creates prerequisites for its successful development and helps to overcome emerging obstacles.

The up-to-date idea of the innovator allows us to say with confidence that the high level of individualism determines the success of the activity of creating new of processes. Innovators generally rely on their ingenuity and personal participation in the process of creating and implementing new concepts. In most cases, they work autonomously, but at the same time they have a significant impact on the innovative work of their colleagues. The presence of innovators is assessed as the main criterion that distinguishes successful from unsuccessful innovation projects. Innovators in the field of business technology are similar to their colleagues in the field of industry in their purposefulness and individual approach, but they are often not the generators of ideas or carriers of knowledge needed to create a new product, service, technology, etc. Their creative potential depends on the representatives of the highest management units, who help them to reveal their potential and provide the necessary resource base for the successful realization of the ideas. Often, the basis of a new, successful process lies in the efforts of senior management. At the same time, the innovators in the field of business technologies, undoubtedly, do not play an insignificant role in the successful implementation of the innovation projects initiated by the management. Globally viewing the problem, it can be noted that the ingenuity and creative potential of one or another national culture and the successful development of new products are directly related to the level of individualism.

Collectivism, as the antithesis of individualism, can also be attributed to the factors that have a positive impact on the process of creation of process innovations. The Japanese approach to developing new of processes can serve as a typical 
supporting example. In Japan, collectivism is one of many factors influencing the innovation process. For example, an integral part of Quality Function Deployment (QFD) technology and the Quality Circle program, as well as many other similar programs, are the working groups-a direct manifestation of collectivism. Japanese working groups are characterized by strong mutual support and consensus. Feelings of empathy and an inner commitment to contribute to the common work set Japanese new product developers apart from their counterparts in other parts of the world. Research on the design and matrix structure on a global scale confirms the indisputable role of group orientation in facilitating the process of creating new products. As a result of studying hundreds of programs for new product/service development, it has been found that design and matrix structures have a significantly stronger impact on the development process than functional ones. So, the collective approach to creating new products is more effective than the individual. When the level of communication, cooperation and harmony is high, i.e., there is a readiness for coordinated work and common goals, the probability of success in creating new products increases significantly.

The results of practical research on the individual and collective approach to the development of new processes are contradictory. On the one hand, individualism promotes the development of new processes, on the other-collectivism also has the same influence. This obvious paradox is removed by a more detailed examination of the stages of the innovation process. As noted earlier, the concept of a two-stage innovation process, including the initiation and implementation stages, has recently emerged. At the initiation stage, the priority task is to develop the most viable, highly feasible ideas by maximizing the range of approaches to their development. No less important requirements are the application of less strict, non-restrictive methods of thinking, which encourage any manifestation of mutual trust, participation in common work, recognition of the achievements of colleagues. That is why the initial stage of the innovation process must be led by people who are firmly convinced of the importance and value of the idea and, therefore, at this stage, individualism is more important. Conversely, at the implementation stage, cohesion and unanimity of the team is needed, as the basic concept of the new product has already been developed and making radical changes can only increase the cost of financial resources and time needed to implement the innovation project. New process developers need to work closely with each other so that the project does not go beyond the set budget and set time limits. In this sense of the implementation stage collectivism is more important. Research on innovation infrastructures shows that companies pursuing an active innovation policy, aiming to encourage the freedom of thought and action of developers, use free rather than a strictly regulated structure at the stage of initiating the new product. Conversely, the implementation stage requirements to the structure are stricter in order to achieve enhanced coordination and control over the implementation of the innovation project. 


\subsection{Case study of Tomika-Metal JSCo-Bulgaria}

\subsubsection{History of the company}

Tomika-Metal JSCo was founded in 1992 in Plovdiv (Tomika-Metal, 2021). It is a large company, whose activities are manufacturing and assembling of stainlesssteel armature of highest quality, tanks and equipment for food-processing, cosmetic and chemical industry. Today Tomika-Metal JSCo is a company with strong and steady presence both on the Bulgarian and the International market. Tomika-Metal JSCo constantly enlarges the range of manufactured products and the market for its sales. The company has its own production base consisting of three plants located in Plovdiv, Svishtov and Chirpan with total industrial area of more than $35000 \mathrm{~m}^{2}$. The mechanical workshop is situated on covered heated area of $15000 \mathrm{~m}^{2}$ and has two distinguished sectors-"Mechanical treatment" and "Welding". The full set of machines for mechanical processing combined with lifting equipment is prerequisite for flexible and effective manufacture. The constructive-technological team works out its own constructive and technological documentation on the basis of solid preparation, gained experience and high-quality collaboration with Solid Works. The company have abilities for $\mathrm{CNC}$ plasma, guillotine, circular and band cutting. Tomika-Metal JSCo cuts out and bends preparations from round, profile and foliate steel, grinding of cylindrical, prismatic and corps details. It is processing separated details and constructions with multiform geometry, weight and complexity.

The company has column and boom machines, sheet welding machines and specialized installation for frontal and corner welds. Its welders are certified. Basic methods for welding in protected environment are WIG and MIG-MAG. Independent control of welds / from outside companies/by client's requirement is conducted. The company provides full tracing and transparency of production process; control of geometrical dimensions, in conformity with constructive documentation; control of finishing works; $100 \%$ final control of ready product; conformity with technical parameters of ready product.

Reliability and safety of equipment and installations manufactured by TomikaMetal JSCo are repeatedly proved. The products marked with TM INOX have been acknowledged many certificates. They have successfully passed many tests of Bulgarian and international certifying organizations. Tomika-Metal JSCo is a winner of two gold medals from international exhibitions and prize for most essential innovation in utilization of Solid Works.

Using their own potential, the company offers:

- engineering, design, manufacture and delivery of equipment, assembly on place, start in action, guarantee and out-of-guarantee service;

- reconstruction-introduction of new technological level in companies, using engineering solutions and modern equipment; 
- modernization - partial substitution of existing equipment which aims at economy of resources and manufacture premises.

Tomika-Metal JSCo offers its clients an exceptional opportunity, concerning the choice of equipment, which is guaranteed by company's machinery stock (metal cutting and metal processing machines), the choice of optimal technology and the highly qualified personnel.

The company management believes that its clients are most important. This is the reason for doing its best in order to contribute to the client success. The main aim of the company is to enlarge the scope and quality of its services. The company does that through unification and combination of experience, knowledge and skill of its experts with requirements of its clients. Long production experience, team of qualified specialists, permanent ambition for perfection and modern production equipment-this is the winning formula, which guarantees perfect performance of every project.

In 2017 Tomika-Metal JSCo developed the project for financing by the operational program "Innovation and competitiveness", co-financed by the European Union through the European Regional Development Fund, within the procedure "Support for the implementation of innovations in enterprises". The project was approved and the company concluded a grant agreement with the Ministry of Economy (Bulgaria) for the implementation of the project "Implementation in the production of innovative multifunctional installation for production and storage of beer from classic and specific raw materials in Tomika-Metal JSCo", total value of BGN 2860400 or EUR 1462 649,33 (including BGN 1215670 or EUR 622 028,25-European, and BGN 214,530 or EUR 109 701,95-national co-financing) with a duration of 18 months. The project aim was to diversify the activities of Tomika-Metal JSCo by introducing into production an innovative product-a multifunctional installation for production and storage of beer from classic and specific raw materials-the company's own development. Within the project, a laser machine, a four-shaft hydraulic sheet bending machine, a CNC press brake, a CNC guillotine, a mobile lathe, and a pipe cutter were purchased and put into operation.

\subsubsection{Results and solutions of innovative process}

In connection with the implementation of the project the Tomika-Metal JSCo developed new product accompanied with services new for it, did engineering and technical testing, analysis and certification activities to support production. The company bought new hardware and software, set up computer-related information services.

At the company level it was identified processes and activities, that are not working at good level or can be improved as well as it was determined if that helps them 
deliver better value. At the team level, the company implemented rapid processes for analysis and assessment of the current situation and timely tacked steps to develop innovations based on rapid retrospective analysis.

Generally, within the scope of the project it was tested with various simulation models and projects related to possible options for combining new or improved methods of production, delivery and implementation of ancillary activities to determine whether and to what extent the changes can provide better value.

As a result, the implementation of the project Tomika Metal JSCo achieves a significant increase in its key performance indicators (KPI). The following positives are considered:

- Company results:

- reduced production costs per unit of product / service provided;

- reduced time for the production of the product and the performance of the accompanying services;

- increased number of manufactured products / services provided for a similar period of time;

- improved quality of communication with customers.

- New value generated as a result of:

- changes in working methods and logistical improvements, combined with organizational changes in the work regime of staff, forms of work organization and flexible forms of work organization.

- New value generated by internal stakeholders:

- two new business partners with invested capital;

- increased by $5 \%$ the number of company users;

- increased by $15 \%$ cash inflows.

\section{Questions / tasks}

1. Define the terms "process" and "business process".

2. What are process innovations?

3. What approaches can be applied in defining the processes in the company?

4. What are the main characteristics of business innovation?

5. What are the three types of business processes within which complex solutions in the form of process innovations can be identified and implemented?

6. What are the main differences in defining the scope and content of process innovations in the last two editions of Oslo Manual? What are the probable reasons for these changes, in your opinion?

7. Give examples of successful process innovations. 


\section{References}

American Society for Quality. (March 24, 2021). What is innovation? Retrieved from https://asq.org/ quality-resources/innovation

Brown, S. P. (2008). Business processes and business functions: a new way of looking at employment. A new BLS classification system used in conjunction with the Agency's Mass Layoff Statistics program yields fresh information on business processes and functions affected by mass layoff events. Retrieved January 14, 2021 from www.bls.gov/mlr/2008/12/art3full.pdf

Databerg. (April 11,2021). Transforming hidden data into powerful business insights. Guide to process innovation: definition +7 ways to promote it. Datumize. Retrieved from https://blog.datumize. com/guide-to-process-innovation-definition-7-ways-to-promote-it

Differential (March 20,2020). The 3 types of innovation: Product, process, \& business model. Retrieved February 3, 2021 from https://www.differential.com/posts/the-3-types-of-innovation-product-process-business-model/

Doblin.com. (2013). Ten types tactics overview. Doblin. Deloitte Business. Retrieved March 3, 2021 from https://doblin.com/dist/images/uploads/TenTypesInnovation.pdf

Eurostat. (2018). Glossary of statistical terms. Retrieved January 9, 2021 from http://ec.europa.eu/ eurostat/statistics-explained/index.php/Glossary:Business_functions

Eurostat/OECD. (2020). Oslo Manual 2018: Guidelines for collecting, reporting and using data on innovation, 4th edition. The measurement of scientific, technological and innovation activities. Luxembourg/Paris. https://doi.org/10.1787/9789264304604-en

Innovating society. (December 21, 2020a). Product innovation and process innovation-Characteristics, differences and examples. Retrieved from https://innovatingsociety.com/product-innovation-and-process-innovation-characteristics-differences-and-examples/

Innovating society. (December 21, 2020b). Doblin-10 types of innovation. Retrieved from https:// innovatingsociety.com/doblin-10-types-of-innovation/

KGiSL (March 13, 2020). Process innovation: Enabling change by technology. Retrieved May 26, 2020 from https://www.kgisl.com/gss/process-innovation-enabling-change-by-technology/

Panteleeva, I. (2013). Upravlenie na inovatsiite v industrijalnoto predprijatie. Svishtov: AI Tsenov. [Пантелеева, И. (2013). Управление на иновациите в индустриалното предприятие. АИ «Ценов»].

Process innovation steps. (2016, January 28). Retrieved March 28, 2021 from https://study.com/academy/lesson/process-innovation-steps.html

Techopedia. Dictionary. (December 16, 2020). Definition: Business-process. Retrieved from https:// www.techopedia.com/definition/1168/business-process

Terjesen, S., \& Patel, P. C. (2015). In search of process innovations: The role of search depth, search breadth, and the industry environment. Research Article. 43(5), 1421-1446. https://doi. org/10.1177/0149206315575710

Tomika-Metal (2021). History. Retrieved May 21, 2021 from http://www.tomika-metal.bg/Page/ cHistory.html

Upadhyay, I. (November 10, 2020). What is process innovation? Everything to know in 4 easy points. Retrieved April 27, 2021 from https://www.jigsawacademy.com/blogs/design-thinking/process-innovation/

Varamezov, L. (2005). Inovatsionen menidjmant. Svishtov: AI Tsenov. [Варамезов, Л. (2005). Иновационен мениджмънт. АИ «Ценов»].

Varamezov, L. (2013). Inovatsionen menidjmant. Svishtov: AI Tsenov. [Варамезов, Л. (2013). Иновационен мениджмънт. АИ «Ценов»]. 